\title{
SHALE PROSPECTIVITY ONSHORE BRITAIN
}

Antoinette L. Harvey, Oil and Gas Authority, 21 Bloomsbury Street London WC1B 3HF lan J. Andrews and Alison A. Monaghan, British Geological Survey, The Lyell Centre, Research Avenue South, Edinburgh EH14 4AP

Email address of corresponding author: toni.harvey@oga.gsi.gov.uk

\section{ABSTRACT}

DECC commissioned BGS to summarise the available geological knowledge, integrate new seismic mapping and well analysis and make preliminary in-place resource assessments for the three most prospective areas onshore Britain to foster a greater understanding of the unconventional shale resource potential in advance of the 14th Landward Licensing Round.

The first study, published in June 2013, reviewed the Carboniferous Bowland-Hodder shales across central Britain where a large volume of in-place gas was assessed to be present. The second study, of the Jurassic shale of the Weald Basin in southern England, published in May 2014, concluded that due to insufficient burial there was no significant Jurassic shale gas potential, but there could still be shale oil resources at several levels in the centre of the basin. The third study, published in June 2014, covered the Midland Valley of Scotland where both oil and gas potential in Carboniferous shales was identified.

A large volume of in-place gas and oil resource has been assessed to be present. However, not enough is known at the time of writing to estimate a recovery factor, or to estimate potential producible reserves.

This paper summarises the results of the BGS reports and their impact on the subsequent licensing process in England.

\section{Introduction}

The production of gas (and oil) from mature, organic-rich shales is one of several successful attempts to exploit unconventional oil and gas through advances in technology. The 'shale gas revolution' was initiated in the USA in the 1980s, but has been slower to develop elsewhere in the world. There are now tens of thousands of shale wells across many US states and in 2013 shale gas accounted for about $47 \%$ of the total US dry natural gas production (USEIA 2015). In contrast, shale gas in the UK received little other than academic interest until about 2006, ahead of the 13th Landward Licensing Round when a small number of companies expressed an interested in shale gas exploration (Selley 2005, 2012).

Now in early 2016, shale gas exploration in the UK still remains in its infancy. A small number of wells have been drilled on 13th Round licences (e.g. Preese Hall 1, Grange Hill 1 and Becconsall 1 were drilled by Cuadrilla Resources Ltd in 2011-12) and many 14th Round licences have been offered, but a full multi-stage hydraulic fracture test of a horizontal well has still to be achieved.

This paper explores recent advances in our knowledge of the shale basins of the UK, highlighting the current level of available data used to develop a model which predicts the presence of in-place shale oil and gas volumes, but is inadequate to make an assessment of its likelihood to produce oil and gas.

\section{BGS Resource Assessment Study commissioned by DECC}

To foster a greater understanding of the shale gas resource potential of the UK in advance of launching new licensing in the 14th Landward Licensing Round, the UK Department of Energy and Climate Change (DECC) commissioned British Geological Survey (BGS) reports, summarising the existing geological knowledge, integrating new seismic mapping and well analysis and making 
preliminary in-place resource assessments for three areas (Figure 1). These reports differed from previous DECC-published reports because of new, detailed interpretations of diverse data, new RockEval organic geochemical and XRD analysis, basin modelling etc. and the integration of confidential industry data together with a collaborative approach taken with government regulators and academia, and a peer review of the final reports. Meetings were held with industry experts to discuss commercially confidential information and understand their detailed knowledge of their respective licenced areas.

Fig. 1 DECC/BGS shale study areas, licensed acreage (as of November 2013) and blocks offered in the 14th Landward Licensing Round in blue that had been the subject of a Strategic Environmental Assessment. Figure 16 shows licences which were subsequently offered in the 14th Round.

The first stage of study for each area was an integration of the well and outcrop data with an interpretation of all the existing seismic reflection data. Most of these data are mixed vintage short seismic lines because before 2015, seismic data could only be acquired over extant licence areas. The UK Onshore Geophysical Library (UKOGL) provided their full archive of seismic data to this study. UKOGL is a self-sustaining, independent charity which receives no funding from government and provides open access to onshore seismic data and geotechnical reports for the national archive (www.ukogl.org.uk).

\subsection{Previous BGS Studies}

In 2010, DECC commissioned BGS to summarise the BGS-held information related to shale gas prospectivity in the UK (DECC 2010). That study identified three prospective shale intervals: the Jurassic, Carboniferous and Cambro-Ordovician, each with a broad distribution (Figure 2). 3D seismic mapping and thermal maturity evaluation were not within the scope of this study so the resulting map of the Jurassic area reflected the entire Jurassic outcrop and subcrop, with the caveat that these are not necessarily prospective at very shallow depths. DECC (2010) identified where there were adequate data for further study in three areas, but that additional data would be required to progress the evaluation on the Midland Microcraton or shale basins offshore.

Fig. 2 Distribution of the three principal prospective shale units in the UK (DECC 2010). A determination of subsurface distribution, shale maturity and present-day depth of burial was considered essential to refine these into prospective shale areas.

Fig. 3. Summary of the stratigraphic relationships between the main shale-bearing units within the three study areas. Units in bold are the main shale and shale-bearing units. Volcanic units have been omitted from the Midland Valley of Scotland stratigraphy.

\section{Shale Characteristics}

The detailed assessment of the three prospective shale areas was based on a list of successful shale play characteristics shared by the United States Geological Survey (D.L. Gautier pers. comm.) although some criteria were added and amended to reflect the geological differences between US and UK shale basins (Table 1), as well as recently published research (e.g. Jarvie 2012a, 2012b). In the Weald Basin, for example the gamma log response is anomalously low even where shales are organic-rich. Thus the cut-off used was selected on a well-by-well basis taking into account the total organic carbon (TOC) and shale gamma-log values, which are typically $<100$ API. This contrasts with the Bowland Shale Formation and the Carboniferous of the Midland Valley of Scotland, where highgamma zones are widespread. A comparison of the three different basins demonstrates their different characteristics (Table 1).

Table 1. The characteristics of a succcessful shale play (after Charpentier \& Cook 2011 and references in Table 1 of Andrews 2013) as applied to the UK. Note: * the difference in the 'depth minimum' figures reflects an evolving understanding of what might be considered to be an 'accessible/viable' shale volume as obtained from publications and experts (e.g. Charpentier \& Cook 2011, USEIA 2013). In the Midland Valley of Scotland, the presence of abandoned mine workings is 
also taken into account. Subsequent to the three studies, the Infrastructure Act of 2015 (England and Wales only) restricted high volume hydraulic fracturing to depths greater than $1000 \mathrm{~m}$.

\section{Resource assessment method}

Fig. 4 Overview of the method used to calculate mature shale gas and shale oil volumes by Andrews (2013, 2014) and Monaghan (2014).

A 3D geological model-driven, in-place resource approach similar to that used by TNO (2009) was adopted in the absence of any shale gas or shale oil production figures from the UK, and the reluctance to use what could prove to be unrepresentative US production analogues,. The method is explained in detail by Andrews $(2013,2014)$ and Monaghan $(2014)$ and is summarised in Figure 4. Even using this approach, relevant input data were limited or lacking, and in the case of gas-filled porosity and adsorbed gas content it was necessary to use general approximations within truncated confidence limits (see Appendix A in Andrews 2013).

The input parameters were (a) the mapped distribution and depth to prospective shale horizons, (b) the mapped distribution and thickness of organic-rich shales (> $2 \% \mathrm{TOC})$, and (c) the mapped depth of the oil and/or gas window based on maturity data from wells and a study of burial history including uplift figures. Minimum vitrinite reflectance values of $0.6 \%$ and $1.1 \%$ were used as cut-offs for the oil and gas window respectively. Other scenarios are possible, with the onset of the oil window variously taken at $0.5-0.6 \%$ and the onset of the gas window taken at $1.1-1.3 \%$.

For in-place gas volumes, the standard approach of summing free gas and adsorbed gas (see TNO 2009) required the estimation of (a) gas-filled porosity (mean of $3 \%$ used, with a two standarddeviation variation and cut-offs at $0.5 \%$ and $10 \%$ ), (b) present-day depth of burial (and hence pressure - assumed to be normally pressured, although slight overpressure could be present), (c) the bulk density of shale $\left(2.55-2.60-2.65 \mathrm{~g} / \mathrm{cm}^{3}\right.$ used) and (d) the adsorbed gas content (0.5 to 2.0 $\mathrm{m}^{3} /$ ton used).

The calculation of in-place oil volumes required (a) average $\mathrm{S} 1$ values (mgHC/gRock) from Rock-Eval analyses for each unit corrected for evaporative loss of $34.5-46.4-58.7 \%$ (using Michael et al.

2013's equation for oil gravities of $\left.35-40-45^{\circ} \mathrm{API}\right)$, (b) the bulk density of shale $(2.55-2.60-2.65$ $\mathrm{g} / \mathrm{cm}^{3}$ used) and (c) the oil density $\left(0.80-0.825-0.85 \mathrm{~g} / \mathrm{cm}^{3}\right.$ used based on $35-40-45^{\circ}$ API oil).

The final figures (see Table 2) were presented as a P90-P50-P10 range based on a Monte Carlo simulation using the input parameters outlined above.

\section{The Bowland Shale}

The Carboniferous Bowland-Hodder marine shales (locally interbedded with sandstones and/or thin limestones) were deposited in a complex series of tectonically active basins across central Britain during the Visean and Namurian epochs (see Fraser \& Gawthorpe 1990). The shales are thickest in the basin depocentres (i.e. Bowland, Blacon, Gainsborough, Widmerpool, Edale and Cleveland basins) where sufficient mature organic matter has generated considerable amounts of conventional oil and gas. Overlying oil and gas fields attest to the capability of this shale to produce hydrocarbons.

Fig. 5 Gross thickness of the Bowland-Hodder unit across central Britain as derived from the interpretation of seismic data (Andrews 2013). The extent of the Bowland-Hodder unit in Humberside area remains uncertain and greater thicknesses may be present in the Cheshire Basin. The location of the cross-sections $A$ (orange), $B$ (blue) and $C$ (green) illustrated in Figure 7 are shown.

While some of the of the Bowland-Hodder shales (e.g. the Lower Bowland Shale unit) share favourable properties with the successful North American shale plays, the UK basin configuration and tectonic history are very different. The discrete basins across central Britain are much smaller and they are narrow fault-bounded depocentres with significant syn- and post-depositional tectonic overprinting. The most significant difference is the thickness of the gross shale units, with over 3500 $\mathrm{m}$ in the basin depocentres (Figure 5), as compared to tens of metres in producing North American analogies. 
There are only 64 wells which penetrate over $15 \mathrm{~m}$ of shale and within these only limited core is available, so a full evaluation of the most prospective intervals was not possible, nor was it possible to quantify the "hybrid" play potential of brittle units encased in shale. However, two genetic units; the Upper and Lower Bowland-Hodder units were mapped across central Britain (Figure 6).

Many of the wells penetrated the upper part (Figure 6) of the Bowland-Hodder sequence in the basins which thins across most of the carbonate platforms, following the drowning of the highs. Locally condensed zones of laterally continuous intervals, rich in organic material could be correlated, indicating the relative stability in the Upper unit. In the Lower unit of the Bowland-Hodder sequence thicker, syn-rift, shale-dominated facies passed laterally to age-equivalent limestones on adjacent highs and platforms. The presence of slumps, debris flows and gravity slides (Gawthorpe \& Clemmey 1985 , Riley 1990) is evidence for relatively steep slopes, and a combination of syn-depositional tectonics, fluctuating sea levels, climate change, and evolution of the carbonate ramps/platforms surrounding the basin resulted in a variety of sediments being fed into the basin at different times. However, there is so little well control for the Lower unit in the deep basins, that it is unclear how regionally correlative these intervals are. This subdivision provided a useful framework for the breakdown of the resource estimation into the less understood Lower unit and the better wellcontrolled Upper unit, but this division is a generalized model which will evolve on a basin specific basis as more drilling and testing data becomes available.

Fig. 6 Identification of the Upper and Lower Bowland-Hodder units in the Widmerpool Gulf (Andrews 2013). The base of the Lower Bowland-Hodder unit is not reached in Old Dalby 1 and Kinoulton 1. In Rempstone 1, the base is a faulted contact with Caledonian granodiorite at $1131.2 \mathrm{~m}$ measured depth.

\subsection{Bowland-Hodder Thermal Maturity and Resource Assessment Assumptions}

Following the identification of organic-rich shale thicknesses, a 3D geocellular model for the two units was constructed and the volumetric calculations were limited by two key factors - minimum depth below the surface and thermal maturity. The shale gas assessment methodology used by the USGS assumed the minimum depth to be $1500 \mathrm{~m}$ below surface (blue dash line on Figure 7 schematic cross sections below) and this was used for this study, limiting the extent of potentially exploitable prospectivity of inverted basins. An example of exclusion by cut-off depth is near well Weeton 1 , where thermally mature shale is close to the surface (Figure $7 \mathrm{C}$ ).

In the schematic cross sections of Figure 7, the Upper Bowland-Hodder is the green unit and the Lower unit is orange. This estimate of the present-day thermal maturity profile was determined by first extracting a generalised Ro versus palaeo-depth relationship from all available wells and then using that to provide an estimate of the depths of the $R_{0}=0.6$ and $R_{0}=1.1$ iso-maturity lines in relation to the depth converted seismic horizons, taking into account an estimate of the total regional uplift. The darker colour intensity depicts proposed gas-mature intervals $\left(R_{\circ}\right.$ 1.1-3.5), and lighter indicates that the interval is in the oil window $\left(R_{0} 0.6-1.1\right)$. It is evident that most of the Bowland-Hodder sequence falls below the top of the gas mature window and the resource assessment remit was limited to gas, although there is also potential for liquids.

Fig. 7 Schematic cross-sections through the key Bowland-Hodder basins in central Britain showing the mature sequences below a $1500 \mathrm{~m}$ cut-off (Andrews 2013). The location of these sections is indicated on Figure 5.

The resultant estimation of the prospective volume of mature shale had a large areal extent (Figure 8), and has not been limited by areas with access limitations in environmentally sensitive or urban areas. A guide to resource vs. reserves estimation is available through the OGA website. Despite this, misleading predictions of potential gas production were made by the media by multiplying the entire in-place gas resources with a US average recovery factor. Given the clearly stated differences in sequence thickness in very different basins this is clearly inadvisable, and addressing perceived expectations continues to be a challenge for OGA. 
Fig. 8 The estimated distribution of mature Bowland-Hodder shale across central Britain (Andrews 2013). The areas shown are constrained by the $1500 \mathrm{~m}$ depth cut-off. Contains Ordnance Survey data () Crown copyright and database right 2016.

\section{The Weald Basin}

The second study covered the potential for shale oil and shale gas within the Jurassic of the Weald Basin of southern Britain (Figure 1), and reviewed the area's long history of oil and gas exploration since hydrocarbons were first encountered by chance in the 19th Century. There are currently 13 largely unobtrusive producing fields here, some almost 30 years old (see Andrews 2014).

Marine shales were deposited at several intervals during the Jurassic in the Weald Basin, which comprises several fault-controlled sub-basins extending into northern France. Five units within the Jurassic interval contain organic-rich marine shale: 'Mid Lias Clay' and 'Upper Lias Clay', Oxford Clay, Corallian Clay and Kimmeridge Clay (Figure 3). In the Blue (Lower) Lias, total organic carbon (TOC) is much higher further west, in the Wessex Basin where it sources the Wytch Farm oilfield (Ebukansen \& Kinghorn 1986b). However, organic carbon contents are relatively lean (below 2\%) in the equivalent limestones and shales of the study area.

The number of TOC values from core samples in the Weald area were limited and these were augmented by, and used as calibration for, the estimation of TOC using the $\Delta \log \mathrm{R}$ (Passey) method on downhole geophysical logs (Passey et al. 1990, and C.M.A. Gent, S.D. Hannis and I.J. Andrews in Andrews 2014).

Fig. 9 Schematic cross-section through the Weald Basin illustrating the present-day inversion of the basin (Andrews 2014, based on Butler \& Pullan 1990).

\subsection{Weald Basin Thermal Maturity and Resource Assessment Assumptions}

The Mesozoic Weald Basin was inverted during the Cenozoic, with the basin centre being uplifted by an estimated maximum of up to $2280 \mathrm{~m}$ before erosion (Hillis et al. 2008). Estimating the extent of this inversion is fundamental in assessing the depth at which the oil and gas windows currently occur and two methods were used to compare estimates of uplift with previous studies. Firstly, estimated thicknesses of the eroded uppermost Jurassic, Wealden Beds, Lower Greensand, Gault Clay, Upper Greensand, Chalk and Tertiary sections (Figures 9,10) were constructed by extrapolating well and outcrop thickness, and were used in a stratigraphic restoration of the basin (maximum estimated uplift $2060 \mathrm{~m}$ ). An alternative approach, comparing interval velocity vs. present-day mid-point depth was used to corroborate the maximum depth of burial for the basin (maximum estimated uplift $2084 \mathrm{~m}$ ).

The total volume of potentially productive shale in the Weald Basin was estimated using a 3D geological model derived from an interpretation of a grid of 2D seismic data, integrated with the available borehole information. This gross volume was then reduced to a net mature organic-rich shale volume using the maximum, pre-uplift burial depth corresponding to a vitrinite reflectance (using $R_{0}$ calculated from $T_{\max }$ ) cut-off of $0.6 \%$, then modelled for two sensitivities; at $2130 \mathrm{~m}$ maximum burial or an alternative maximum burial at $2440 \mathrm{~m}$ (blue dash lines on the cross section in Figure 10). This volume was further truncated at a depth of $1000 \mathrm{~m}$ below present-day ground level following the most recent shale oil resource assessment method employed by the 2013 U.S. Energy Information Administration World Shale Resource Assessments (USEIA 2013).

Fig. 10 Cross-section showing the distribution of mature shales within the Weald Basin using two burial models and the extent of Cenozoic uplift and erosion (Andrews 2014). The 'O' marks the proposed location of shales currently within the oil window. The uplifted mature areas in the east are constrained by the $1000 \mathrm{~m}$ depth cut-off. The line of section is shown on Figure 11.

In a cross-section through the deepest basis axis (Figure 10), it is evident that not even the deepest Lias shales are predicted to be mature for gas generation. However, all five Jurassic shales are shown to be prospective for oil generation, but only mature and below $1000 \mathrm{~m}$ in the centre of the basin (Figure 11). 
Fig. 11 Summary of areas considered prospective for oil in the Jurassic shale units in relation to the urban areas of southern Britain. The South Downs and New Forest National Parks are indicated in pale orange; Areas of Outstanding Natural Beauty are shown in pale green. Contains Ordnance Survey data (C) Crown copyright and database right 2016.

Potential oil yields were interpreted using S1 data from Rock-Eval pyrolysis analysis, but this measurement of the amount of 'free' hydrocarbons already generated in the source rock and present in the sample contains both true 'free oil' in microscopic pore spaces and 'sorbed oil' within the kerogen particles. A correction to S1 was also made to compensate for evaporative loss since the sample was collected (see Jarvie 2012b, Michael et al. 2013). This S1 component provides an indication of the amount of hydrocarbons that might be in the pore space, some of which might be available to be extracted using fracture stimulation. From the available limited geochemical dataset, only $10 \%$ of Jurassic shales have corrected $\mathrm{S} 1$ values $>2 \mathrm{mgHC} / \mathrm{gRock}$, a value considered as a prerequisite for shale oil extraction by some authors. In addition, by considering the relationship of $\mathrm{S} 1$ to the TOC, an oil saturation index (sensu Jarvie 2012b) was estimated. The oil saturation index for Jurassic shales of the Weald Basin is typically $<35$, rather less than that exhibited by producing shale oil plays in North America which is ideally $>100$, (Jarvie 2012b). In conclusion, exploration drilling and testing of the Jurassic shales is required to determine whether the oil measured in S1 Rock-Eval analysis is movable or trapped in the kerogen.

Hybrid conventional/shale oil plays with low-porosity and impermeable rocks juxtaposed against mature shales may also represent a favourable exploration target in the Weald Basin, e.g. the 'MidKimmeridge micrites' and 'Middle Lias Limestone'. However, the extent of oil resources present in these plays was not determined and so were not included in the published in-place oil volumes (Andrews 2014). There are oil shows in the naturally fractured 'Kimmeridgian micrites' in the Balcombe 1 well, and in 2016, tests in similar strata in the Horse Hill 1 well are reported to have flowed oil (UK Oil \& Gas press release dated 16 February 2016).

\section{The Midland Valley of Scotland}

The third study was of the Midland Valley of Scotland. Four prospective Carboniferous units containing organic-rich ( $>2 \%$ TOC) mature shale (VR $>0.6 \%$ shale oil, VR $>1.1 \%$ shale gas) at suitable depths (> $805 \mathrm{~m}$ ) were identified: the Limestone Coal Formation, Lower Limestone Formation, West Lothian Oil-Shale unit and Gullane unit with the latter two units comprising a number of time-equivalent formations (Figure 3). Thirty seven of the deepest, highest quality and best spatially distributed hydrocarbon wells were synthesised with information from hundreds of boreholes and interpretation of 1800 line $\mathrm{km}$ of variable quality seismic reflection data. A large volume of geochemical, maturity and mineralogical data was compiled (e.g. > 500 TOC, > 1000 VR measurements) from well reports, papers and theses and new BGS analysis (50 samples; see Monaghan, 2014 for details and references).

The Midland Valley of Scotland is reputedly the location of the birth of the oil industry from the refining of oil shale (Hallett et al., 1985). The West Lothian oil-shales were quarried and then heated, or retorted to produce oil - distinctly different to the deeper, mature shale oil target described here. In the 1860s, there were approximately 67 works refining oil-shales in Scotland (Redwood 1897). At its peak in 1912, 26,000 tonnes/year were produced, but production halved after the First World War as a result of competition from cheap imported oil from the Middle East and the discovery of American oil fields. However, oil-shale production remained constant at c. 13,000 tonnes/year up until the 1950's (Hallett et al. 1985). Conventional oil and gas production from the Midlothian field (D'Arcy-Cousland) occurred in the 1930's to 1960's (Hallett et al. 1985).

The Carboniferous strata of the Midland Valley of Scotland are not contained within a simple graben, but have a complex tectonic history resulting in significant faulting and folding of prospective strata (Figure 12). A series of inter-related depocentres and intra-basinal highs including the deep low of the Midlothian-Leven Syncline spanning the Firth of Forth, and the shallower Clackmannan Syncline (Figure 12) are major features mapped using sparse seismic data, historic coal mine plans and wells/boreholes.

Fig. 12 Cross-sections showing maturity and mining-related depth cut-off surfaces as output from the 3D geological model of the Midland Valley of Scotland. Note each cross-section has a different 
horizontal and vertical scale. The modelled surfaces appear irregular and with considerable relief due to the high vertical exaggeration of the section and because smaller faults have been excluded from the model.

Shale prospectivity is further complicated by variable sedimentary lithofacies that were deposited in a variety of environments. For example, the Lower West Lothian Oil-Shale unit palaeogeography (Figure 13) reflects western, lacustrine to eastern, fluvio-deltaic sedimentation with marine incursions. Magmatism has also influenced the shale resource of the Midland Valley of Scotland. Firstly, voluminous extrusive magmatism shortly before, and coeval with, the deposition of the shale prospective succession strongly influenced basin palaeogeography, as well as forming a locally significant proportion of the basin fill succession. Secondly, higher heat flow during the Carboniferous in the western, more volcanically active part of the Midland Valley of Scotland is inferred from maturity data (Raymond, 1991). Thirdly, intrusive magmatism locally enhanced sediment maturity (Murchison and Raymond, 1989).

The prospective strata are up to $3000 \mathrm{~m}$ thick and contain numerous shale-rich intervals within vertically and laterally heterogeneous sequences. Shale units (mudstones, carbonaceous mudstones, siltstones as well as oil shales sensu stricto) vary in thickness from a few centimetres to around $50 \mathrm{~m}$ and are interbedded with sandstone, limestone and coal, as well as igneous rocks. As such, the strata constitute a 'hybrid' shale play, though the volumetrics of the shale resource assessment are based on an estimate of shale lithologies with TOC $>2 \%$ within the mixed succession. TOC contents of 2 $6 \%$ and up to $20 \%$ are commonly observed from mudstone, siltstone, calcareous or carbonaceous mudstone and siltstone, and oil-shale samples. Some (around 3\%) of the samples analysed have corrected free hydrocarbon (S1) content analogous to North American producing plays (e.g. Eagle Ford Shale, Jarvie et al., 2012), indicating the potential for moveable oil (S1 corrected $>100$ $\mathrm{mgHC} / \mathrm{gRock}$ ). In contrast to the Bowland Shale and Weald Basin, oil-prone Type I and gas-prone Type III kerogens appear to be most common. Mixed and Type II kerogen are also present at various levels, consistent with a dominant lacustrine or algal and non-marine source rock with periodic marine influence.

Fig. 13 Lower West Lothian Oil-Shale unit palaeogeography (Asbian stage). Constraining wells (red dots) and boreholes (blue dots) are shown, dashed lines are faults and folds with evidence for active growth.

Fig. 14. Areas considered prospective for oil-mature Carboniferous shale (in blue) and gas mature Carboniferous shale (in red) below a mining-related depth cut-off, Midland Valley of Scotland. Contains Ordnance Survey data (C) Crown copyright and database right 2016.

\subsection{Midland Valley of Scotland Thermal Maturity and Resource Assessment Assumptions}

Historical deep coal mines are widespread across the Midland Valley of Scotland. Some abandoned deep mined strata of the Limestone Coal Formation overlie the prospective shale units (e.g. Black Metals Member and Johnstone Shell Bed) within this same formation. A buffer or vertical separation zone of $305 \mathrm{~m}$ from abandoned coal mines and $805 \mathrm{~m}$ minimum depth cut-off below Ordnance Datum was excluded from potential rock volume model to ensure separation from the abandoned coal mines (Figure 15). Further geomechanical and fracture growth height studies are required to give a more robust figure for a suitable vertical separation from coal mines. The vertical separation distance in the volumetric assessment should not be used as a guide for exploration, well testing or regulation. This paper merely attempts to accommodate a reasonable vertical separation taking into account the heights of the majority of simulated fracture heights documented globally (e.g. Fisher and Warpinski, 2011), but without being overly conservative for an in-place resource estimation in an area where no simulated fracture data exists.

Fig. 15 Sketch illustrating the depth cut-off used in the resource calculation across the Midland Valley of Scotland.

Shales in the Midland Valley of Scotland are more mature than either the Bowland-Hodder or Weald Basins at equivalent present day burial depths, likely due to higher Carboniferous geothermal gradients relating to magmatism (Murchison and Raymond, 1991) combined with uplift estimated at up to $1.9 \mathrm{~km}$ places (Vincent et al. 2010). Over large areas they are mature for oil generation from 
shallow burial depths of only a few hundred metres and gas mature from around $700 \mathrm{~m}$ in some locations. The cut-off depth used in the resource calculation is therefore critical (Figures 12 and 15). The resource estimation method was the same as the Bowland and Weald Basin studies (Figure 4), with the additional use of a percentage shale factor in the heterolithic succession and the depth cut-off related to coal mining (Figure 15).

The estimated prospective extents for shale oil and shale gas (Figure 14) cover a populated area of central Scotland. The Scottish Government imposed a moratorium on granting consents for unconventional oil and gas in 2015 whilst regulatory and environmental work and a public consultation are undertaken.

\section{Regulatory Changes}

Petroleum Exploration and Development Licences (PEDLs) do not give any direct permission for operations such as drilling or hydraulic fracturing to begin, so any company proposing such activity must first obtain all the necessary permissions and consents, including, for example, permission from the surface landowner, planning permission, environmental permits, scrutiny by the Health and Safety Executive, and OGA consents under the provisions of the PEDL. Furthermore, the Infrastructure Act 2015 introduced requirements that must be met before an operator can carry out hydraulic fracturing. These include the assessment of environmental impacts, groundwater monitoring and community benefits and that associated high volume hydraulic fracturing will not take place at a depth of less than 1000 metres. A hydraulic fracturing consent will not be issued unless the Secretary of State is satisfied that these conditions are met.

The Infrastructure Act 2015 also set out restrictions on hydraulic fracturing in protected groundwater source areas and other protected areas. The terms have been defined by the Onshore Hydraulic Fracturing (Protected Areas) Regulations 2015. These regulations ensure that high volume hydraulic fracturing cannot take place above 1200 metres in National Parks, the Broads, Areas of Outstanding Natural Beauty (AONBs), World Heritage Sites and areas that are most vulnerable to groundwater pollution. Separately, the Government has also committed to ensure that high volume hydraulic fracturing cannot be conducted from wells that are drilled from a surface location in these specified protected areas.

Measures were announced in August 2015 stating that planning authorities should deal with applications for shale within the statutory time-frame of 16 weeks or risk being identified as underperforming.

\section{The 14th Landward Licence Round}

In October 2014, DECC received 95 applications for 295 of the blocks offered in the 14th Landward Licensing Round. The Oil and Gas Authority was created as an executive agency of DECC on 1st April 2015. Oil and gas licensing administration transferred from DECC to the OGA on the same day. Following scrutiny of the operators' competency, financial viability, environmental awareness and geotechnical analysis, and a Habitats Regulations Assessment, OGA offered 92 licences in England on the $18^{\text {th }}$ of December 2015.

Following discussion with prospective licensees, and in accordance with the new devolution settlements set out in the Scotland Bill currently before Parliament and the soon to be introduced Wales Bill, the UK Government decided that no new Petroleum Exploration and Development Licences (PEDLs) would be awarded in Scotland or Wales as part of the 14th Round.

Most of the BGS-identified areas with mature shale prospectivity in the Bowland-Hodder basins were now licenced. In contrast, no further licences which identified shale prospectivity were offered in the Weald Basin. Licences were also offered in areas where the applicants identified shale prospectivity outside of the areas covered in these BGS studies. In the $14^{\text {th }}$ Round, primary prospectivity in shales was identified by the applicants on $75 \%$ of the blocks offered.

Fig. 16. BGS Shale Prospective Areas and licences offered in England in the 14th Landward Licensing Round. 


\section{Resource Assessment Conclusions}

The three BGS studies (Andrews 2013, 2014, Monaghan 2014) identified a large volume of in-place unconventional gas and oil in the UK's shales (Table 2). However, until some wells have been successfully tested, not enough is known to estimate a recovery factor or to estimate potential reserves.

Table 2 Comparison of estimated in-place shale gas and oil resources from the three study areas in Britain (Andrews 2013, 2014, Monaghan 2014). Note that an estimate of the shale oil potential of the Bowland-Hodder basins was not made.

\section{Conclusions}

There are many unanswered questions influencing our understanding of the UK's unconventional shale potential, all of which highlight the paucity of relevant well data in the UK's deep basins, and all are key to the accuracy of any estimation of in-place and reserve volumes. Not enough is known to determine which intervals in the Bowland-Hodder deep shale basins have the right characteristics for hydrocarbon production. A deep well penetration is needed in the Weald Basin to confirm that the Jurassic section is not mature for gas and that the organic carbon contents and oil saturation indices are as lean as predicted. In this study, many of the key input parameters used to estimate the in-place shale resource for example, gas-filled porosity, adsorbed gas content, and free oil density, rely heavily on American analogues and very limited UK datasets - gaps which can only be filled by targeted, modern drilling and sampling.

There are many similarities between UK and US shales which provide optimism that exploration will be successful. However, differences in basin geometry and extent, structural complexity and uplift history combine to present several challenges yet to be resolved in terms of exploiting these large modelled resources.

The pace of shale exploration will also be affected by non-geological factors including funding, planning and access restrictions as well as the supply chain, potential engineering optimisation of hydraulic fracturing and wellsite operations. But until the analysis of test results from many wells in each basin is available and their Estimated Ultimate Recovery (EUR) can be made, it will not be possible to predict the commercial viability of the produced hydrocarbons.

\section{Acknowledgements}

The authors wish to acknowledge the input of the following people to the three BGS/DECC reports on which this paper is based. DECC (now OGA) and many other collaborators - BGS: Kevin Smith, Mike Sankey, Steve Banham, Mark Kassyk, Rob Ward, Mike Browne, Sandy Henderson, Kirstin Crombie, Ceri Vincent, Nigel Smith, Chris Gent, Sarah Hannis, Chris Vane, Vicky Moss-Hayes, Simon Kemp, Ian Mounteney, Antony Chaggar, Ed Hough and Sue Stoker, Mike McCormac, Don Cameron, Nick Riley and Alick Leslie (last five formerly of BGS); Regulators: Joy Gray - OGA, lan Davey and Alwyn Hart - Environment Agency, Paul Butler - Scottish Environment Protection Agency and Donald L Gautier - USGS; Industry experts: UKOGL, Cuadrilla Resources, Third Energy, IGas Energy, Aurora Petroleum, Celtique Energie, Nexen, NuTech Energy, Neftex, CONSOL Energy, Dart Energy and Reach Exploration for supplying new and previously unpublished analyses and for instructive and open discussions. External academic reviewers were Al Fraser and Dick Selley - Department of Earth Science and Engineering, Imperial College, London, Andrew Aplin - Department of Earth Sciences, Durham University, Sarah Davies - University of Leicester and Kevin Taylor - University of Manchester. I.J. Andrews and A.A. Monaghan publish with the permission of the BGS Executive Director.

References

Andrews, I.J. 2013. The Carboniferous Bowland Shale gas study: geology and resource estimation. British Geological Survey for Department of Energy and Climate Change, London, UK. 
Andrews, I.J. 2014. The Jurassic shales of the Weald Basin: geology and shale oil and shale gas resource estimation. British Geological Survey for Department of Energy and Climate Change, London, UK.

Charpentier, R.R. \& Cook, T.A. 2011. USGS Methodology for Assessing Continuous Petroleum Resources. U.S. Geological Survey Open-File Report 2011-1167.

DECC. 2010. The unconventional hydrocarbon resources of Britain's onshore basins - shale gas. DECC Promote website, December 2010. https://www.gov.uk/government/uploads/system/uploads/attachment data/file/66172/ukonshore-shalegas.pdf

Ebukanson, E.J. \& Kinghorn, R.R.F. 1986. Oil and gas accumulations and their possible source rocks in southern England. Journal of Petroleum Geology 9(4): 413-428.

Fisher, K. \& Warpinksi, N.R. 2011. Hydraulic fracture growth: real data. Society of Petroleum Engineers SPE 145949

Fraser, A.J. \& Gawthorpe, R.L. 1990. Tectono-stratigraphic development and hydrocarbon habitat of the Carboniferous in northern England. In: Hardman, R.F.P. \& Brooks, J. (eds). Tectonic events responsible for Britain's Oil and Gas Reserves. Geological Society Special Publication 55: 49-86.

Gawthorpe, R.L. \& Clemmey, H. 1985. Geometry of submarine slides in the Bowland Basin (Dinantian) and their relation to debris flows. Journal of the Geological Society of London 142: 555-565.

Hallett, D., Durant, G.P. \& Farrow, G.E. 1985. Oil exploration and production in Scotland. Scottish Journal of Geology 21: 547-570.

Hillis, R.R., Holford, S.P., Green, P.F., Doré, A.G., Gatliff, R., Stoker, M., Thomson, K., Turner, J.P., Underhill, J.R. \& Williams, G. 2008. Cenozoic exhumation of the southern British Isles. Geology 36(5): 371-374. Data repository: ftp://rock.geosociety.org/pub/reposit/2008/2008093.pdf

Jarvie, D. M., 2012a. Shale resource systems for oil and gas: Part 1-Shale-gas resource systems. In: Breyer, J.A. (ed.). Shale reservoirs-Giant resources for the 21st century. American Association of Petroleum Geologists Memoir 97: 69-87.

Jarvie, D.M., 2012b. Shale resource systems for oil and gas: Part 2-Shale-oil resource systems. In: Breyer, J.A. (ed.). Shale reservoirs-Giant resources for the 21st century. American Association of Petroleum Geologists Memoir 97: 89-119.

Jarvie, D.M., Jarvie, B.M., Weldon, W.D. \& Maede, A. 2012. Components and processes impacting production success from unconventional shale resource systems. GEO 2012 Conference, Bahrain, March 2012

Michael, G.E., Packwood, J. \& Holba, A. 2013. Determination of in-situ hydrocarbon volumes in liquid rich shale plays. Unconventional Resources Technology Conference, Denver, Colorado, USA, August 2013. www.searchanddiscovery.com/pdfz/documents/2014/80365michael/ndx michael.pdf.html

Monaghan, A.A. 2014. The Carboniferous shales of the Midland Valley of Scotland: geology and resource estimation. British Geological Survey for Department of Energy and Climate Change, London, UK. 
Murchison, D.G. \& Raymond, A.C. 1989. Igneous activity and organic maturation in the Midland Valley of Scotland. International Journal of Coal Geology 14: 47-82

Passey, Q.R, Creaney, S., Kulla, J.B., Moretti, F.J. \& Stroud, J.D. 1990. A practical model for organic richness from porosity and resistivity logs. American Association of Petroleum Geologists Bulletin 74: 1777-1794.

Raymond, A.C. 1991. Carboniferous rocks of the Eastern and Central Midland Valley of Scotland: organic petrology, organic geochemistry and effects of igneous activity. Unpublished Ph.D Thesis, University of Newcastle upon Tyne.

Redwood, R.I. 1897. Mineral Oils and their Products. E. \& F.N. Spon Ltd., London

Riley, N.J. 1990. Stratigraphy of the Worston Shale Group (Dinantian), Craven Basin, north-west England. Proceedings of the Yorkshire Geological Society 48(2): 163-187.

Selley, R.C. 2005. UK shale-gas resources. In: Doré, A.G. \& Vining, B.A. (eds.) Petroleum Geology: North-West Europe and Global Perspectives - Proceedings of the 6th Petroleum Geology Conference. Geological Society. London. 707-714.

Selley, R.C. 2012. UK shale gas: the story so far. Marine and Petroleum Geology 31: 100-109.

Smith, N., Turner, P. \& Williams, G. 2010. UK data and analysis for shale gas prospectivity. In: Vining, B.A. \& Pickering, S.C. (eds) Petroleum Geology: From Mature Basins to New Frontiers Proceedings of the 7th Petroleum Geology Conference, 1087-1098.

TNO. 2009. Inventory non-conventional gas. TNO-034-UT-2009-00774/B.

U.S. Energy Information Administration (USEIA). 2013. Technically recoverable shale oil and shale gas resources: an assessment of 137 shale formations in 41 countries outside the United States. Report prepared by Advanced Resources International Inc. www.eia.gov/analysis/studies/worldshalegas/.

U.S. Energy Information Administration (USEIA). 2015. Annual Energy Outlook 2015. http://www.eia.gov/forecasts/aeo/

Vincent, C.J., Rowley, W.J. \& Monaghan, A.A. 2010. Thermal and burial history modelling in the Midlothian-Leven syncline in the Midland Valley of Scotland using BasinMod and HotPot. Scottish Journal of Geology 46: 1-18.

Please see complete set of references in detail documents on the OGA website (https://www.gov.uk/guidance/oil-and-gas-onshore-exploration-and-production\#onshore-reports) 


\begin{tabular}{|c|c|c|c|}
\hline Criteria & $\begin{array}{l}\text { Bowland-Hodder } \\
\text { basins }\end{array}$ & Weald Basin & $\begin{array}{l}\text { Midland Valley of } \\
\text { Scotland }\end{array}$ \\
\hline $\begin{array}{l}\text { Shale and } \\
\text { associated } \\
\text { lithologies }\end{array}$ & $\begin{array}{l}\text { Basinal shale } \\
\text { (Bowland Shale } \\
\text { Formation) } \\
\text { otherwise shales } \\
\text { interbedded with } \\
\text { limestone and } \\
\text { sandstone mass- } \\
\text { flow deposits } \\
\text { (remainder of } \\
\text { Bowland-Hodder } \\
\text { Unit). Except in the } \\
\text { Cleveland Basin, } \\
\text { where shales largely } \\
\text { interbedded with } \\
\text { sandstones. }\end{array}$ & $\begin{array}{l}\text { Basinal shales in the } \\
\text { 'Mid Lias Clay', } \\
\text { 'Upper Lias Clay', } \\
\text { Oxford Clay, } \\
\text { Corallian Clay and } \\
\text { Kimmeridge Clay. } \\
\text { These shales are } \\
\text { discrete units mainly } \\
\text { between limestones. }\end{array}$ & $\begin{array}{l}\text { Shale units are } \\
\text { interbedded with } \\
\text { numerous lithologies } \\
\text { including sandstone, } \\
\text { limestone and coal, } \\
\text { as well as igneous } \\
\text { rocks. }\end{array}$ \\
\hline$>2 \%$ TOC & $\checkmark$ & $\checkmark$ & $\checkmark$ \\
\hline $\begin{array}{l}\text { High gamma-ray } \\
\text { values }\end{array}$ & $\checkmark$ & $\checkmark$ & $\checkmark$ \\
\hline $\begin{array}{l}\text { Contains type II } \\
\text { kerogen }\end{array}$ & II and III & II and III & I and III \\
\hline$<30 \%$ clay & $\checkmark$ & $\checkmark$ & $\checkmark$ \\
\hline Net shale $(\mathrm{m})$ & $\begin{array}{l}\text { Up to } 3060-3900 \mathrm{~m} \\
\text { in basins; up to } 100 \\
\mathrm{~m} \text { on platforms }\end{array}$ & $\begin{array}{l}19-300 \mathrm{~m} \text { (combined } \\
\text { total) }\end{array}$ & $\begin{array}{l}\text { Mixed succession up } \\
\text { to } 3 \mathrm{~km} \text { thick with } 0- \\
85 \% \text { net shale }\end{array}$ \\
\hline Shale bed(s) >15 m & $\checkmark$ & $\checkmark$ & $\checkmark$ \\
\hline $\begin{array}{l}\text { Shale oil precursor? } \\
\text { Nearby oil fields? }\end{array}$ & $\checkmark$ & $\checkmark$ & $\checkmark$ \\
\hline Thermally mature? & $\checkmark$ & $\checkmark$ & $\checkmark$ \\
\hline $\begin{array}{l}\text { Oil yield (S1) >2 } \\
\text { mgHC/gRock? }\end{array}$ & $n / a$ & Only $10 \%$ & $\checkmark$ \\
\hline $\begin{array}{l}\text { Oil saturation index } \\
>100 \text { (sensu Jarvie } \\
2012 b \text { ) }\end{array}$ & ?n/a & Typically $<35$ & $\begin{array}{l}\text { Small percentage of } \\
\text { samples }>100 \text {, many } \\
\text { between } 50 \text { and } 100\end{array}$ \\
\hline Structural complexity & Variable & Lower & Higher \\
\hline Minimal uplift & $\begin{array}{l}\text { Maximum 2000+ } \mathrm{m} \\
\text { in Pennines and } \\
\text { Cleveland Basin }\end{array}$ & $\begin{array}{l}\text { Maximum } 2000 \mathrm{~m} \text { in } \\
\text { central and eastern } \\
\text { areas }\end{array}$ & $\begin{array}{l}\text { Maximum } 1900 \mathrm{~m} \\
\text { estimated }\end{array}$ \\
\hline $\begin{array}{l}\text { Resources } \\
\text { evaluated }\end{array}$ & $\begin{array}{l}\text { Gas (and oil - not } \\
\text { assessed) }\end{array}$ & Oil & Oil and gas \\
\hline Depth minimum * & $1500 \mathrm{~m}$ & $1000 \mathrm{~m}$ & $\begin{array}{l}805+m \text { (see Figure } \\
15)\end{array}$ \\
\hline
\end{tabular}




\begin{tabular}{|l|c|c|c|c|c|c|}
\hline & \multicolumn{2}{|l|}{$\begin{array}{l}\text { Estimated in-place shale gas resource } \\
\text { (trillion cubic metres) }\end{array}$} & \multicolumn{2}{l|}{$\begin{array}{l}\text { Estimated in-place shale oil resource } \\
\text { (million tonnes) }\end{array}$} \\
\hline & $\begin{array}{l}\text { Low case } \\
\text { (P90) }\end{array}$ & $\begin{array}{l}\text { Mid case } \\
\text { (P50) }\end{array}$ & $\begin{array}{l}\text { High case } \\
\text { (P10) }\end{array}$ & $\begin{array}{l}\text { Low case } \\
\text { (P90) }\end{array}$ & $\begin{array}{l}\text { Mid case } \\
\text { (P50) }\end{array}$ & High case (P10) \\
\hline $\begin{array}{l}\text { Bowland- } \\
\text { Hodder basins }\end{array}$ & 23.3 & 37.6 & 64.6 & n/a & n/a & n/a \\
\hline Weald Basin & 0 & 0 & 0 & 293 & 591 & 1,143 \\
\hline $\begin{array}{l}\text { Midland Valley } \\
\text { of Scotland }\end{array}$ & 1.4 & 2.27 & 3.81 & 421 & 793 & 1,497 \\
\hline
\end{tabular}




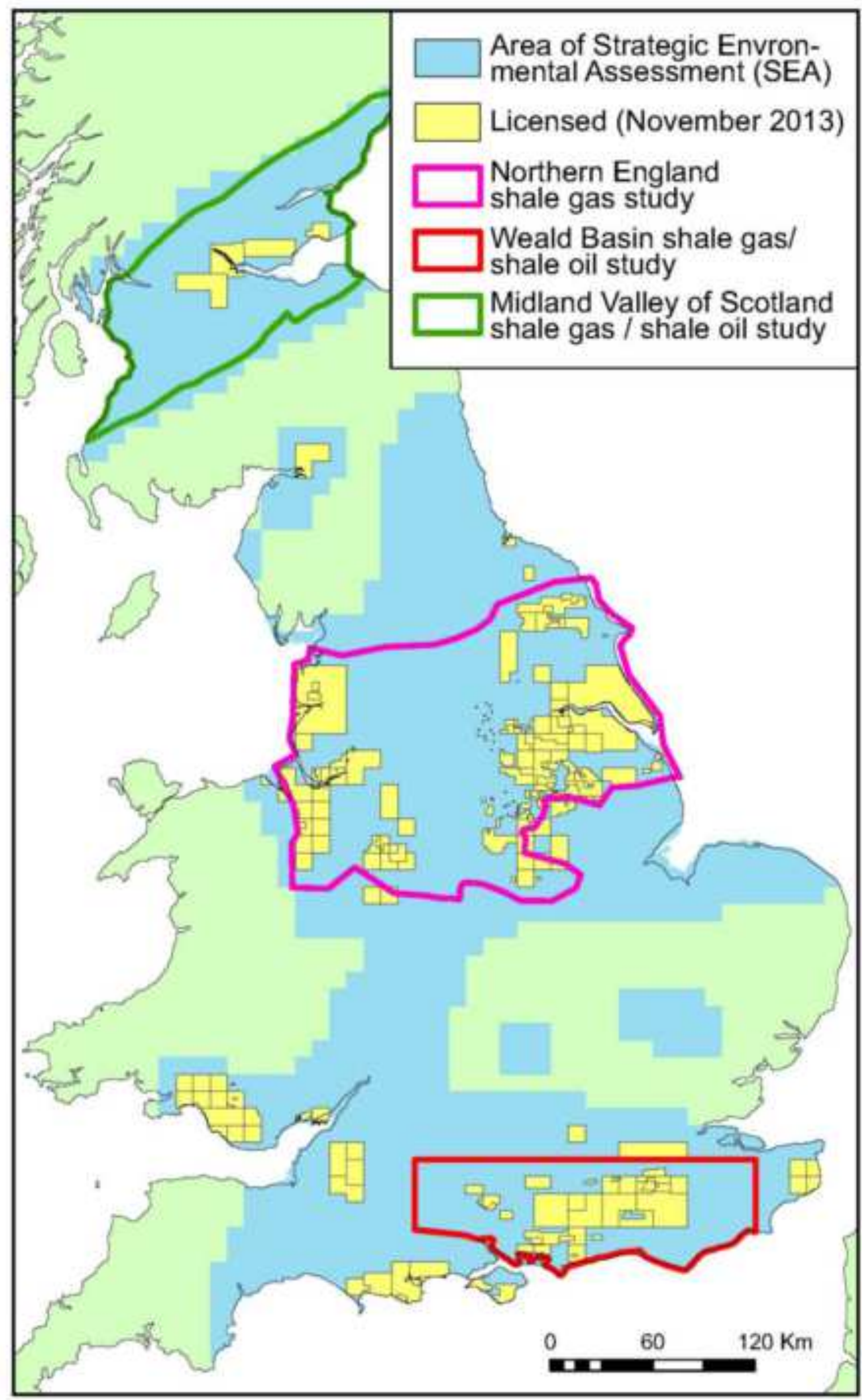




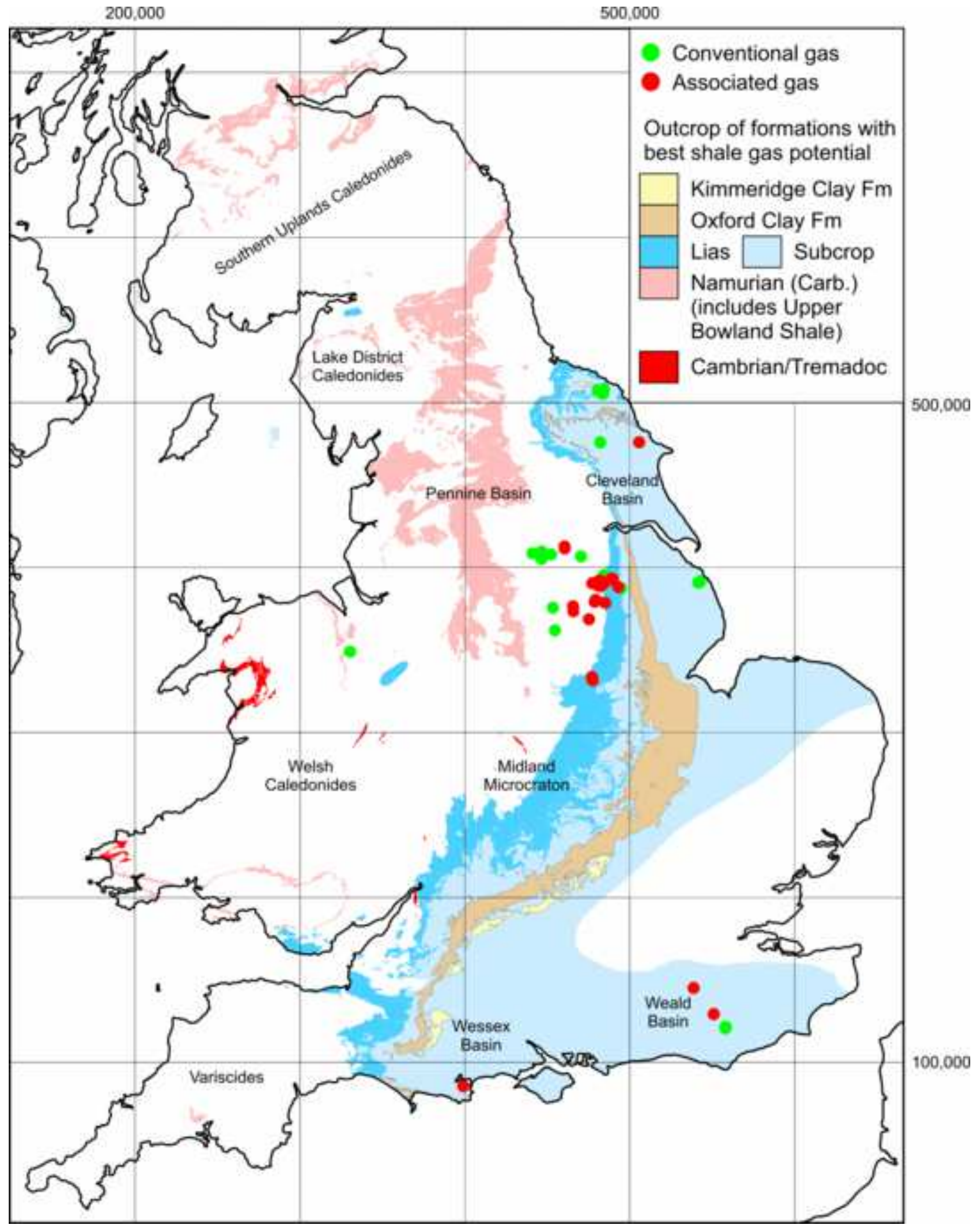




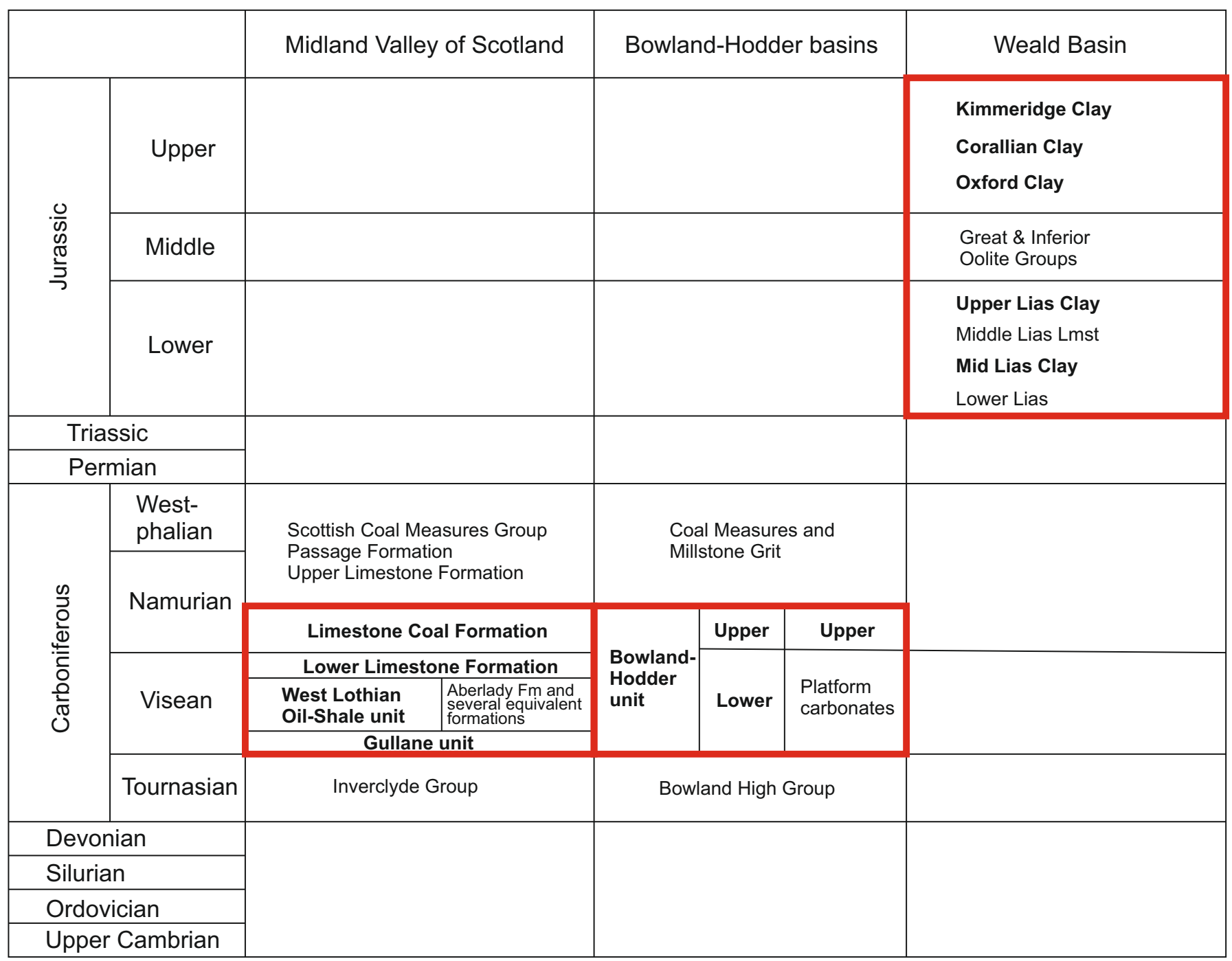




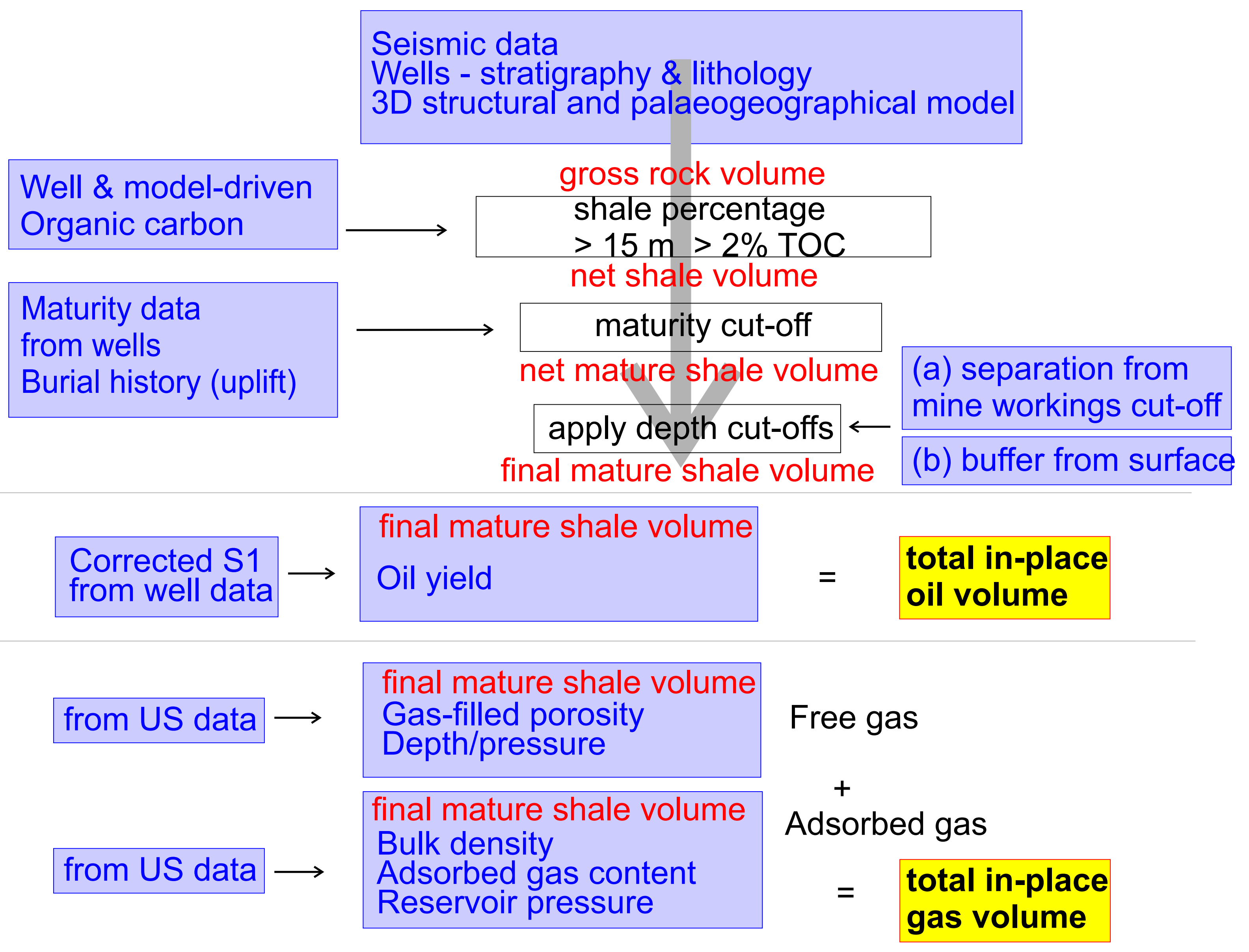




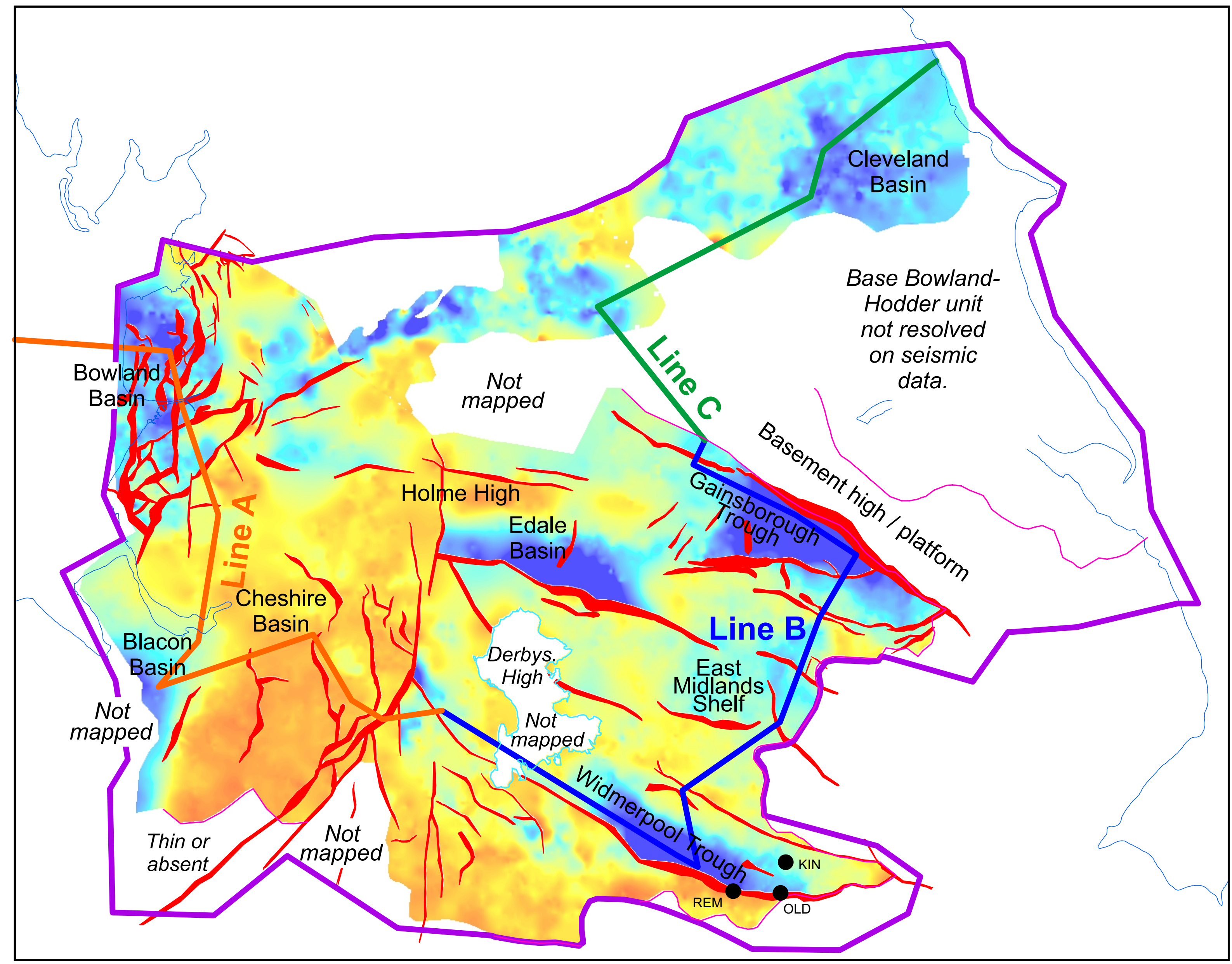

Thickness

Metres

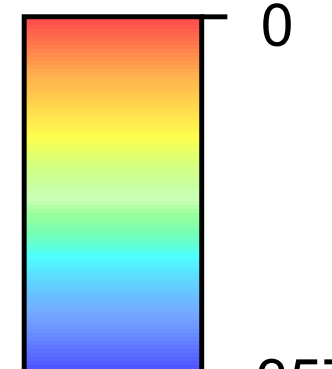

3575

BGS/DECC study area
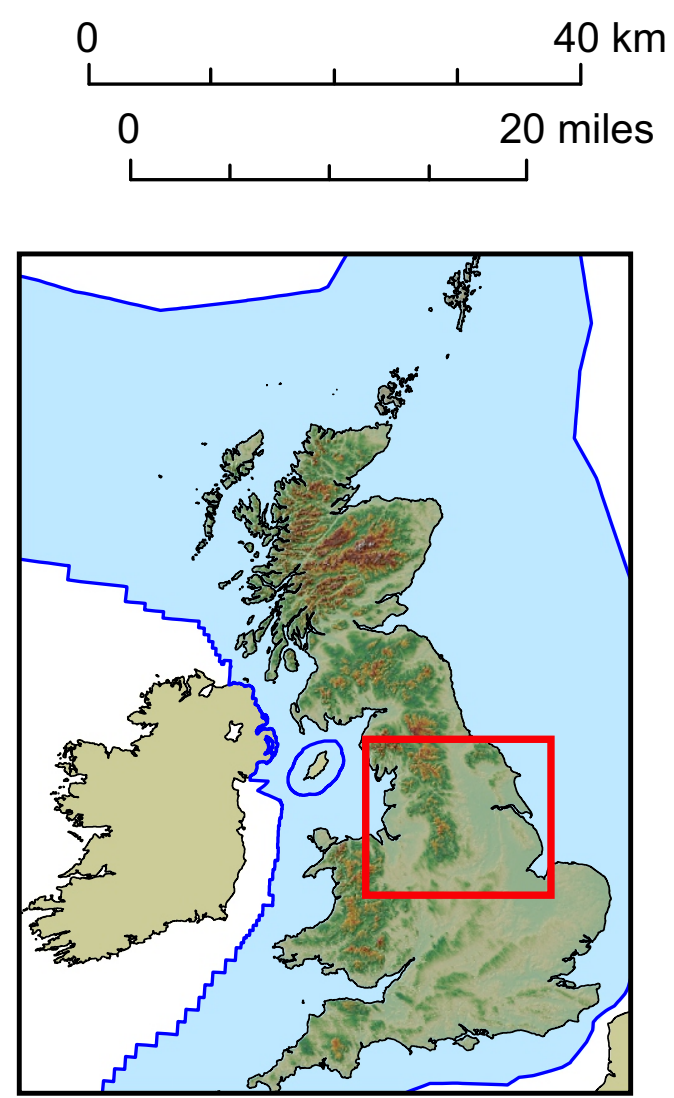


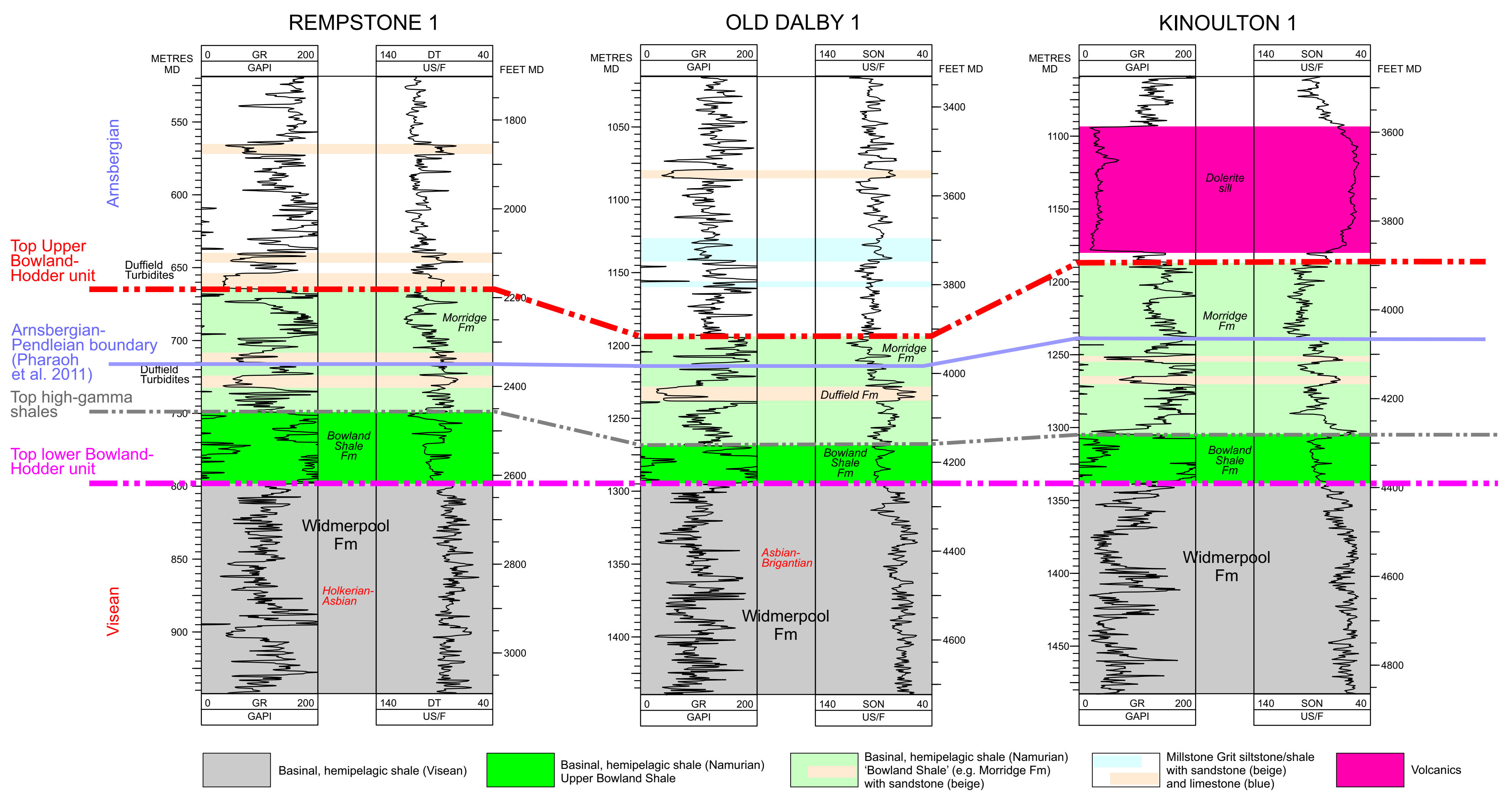

\begin{tabular}{c} 
Duftield \\
Turbidites \\
\hline
\end{tabular}

REMPSTONE 

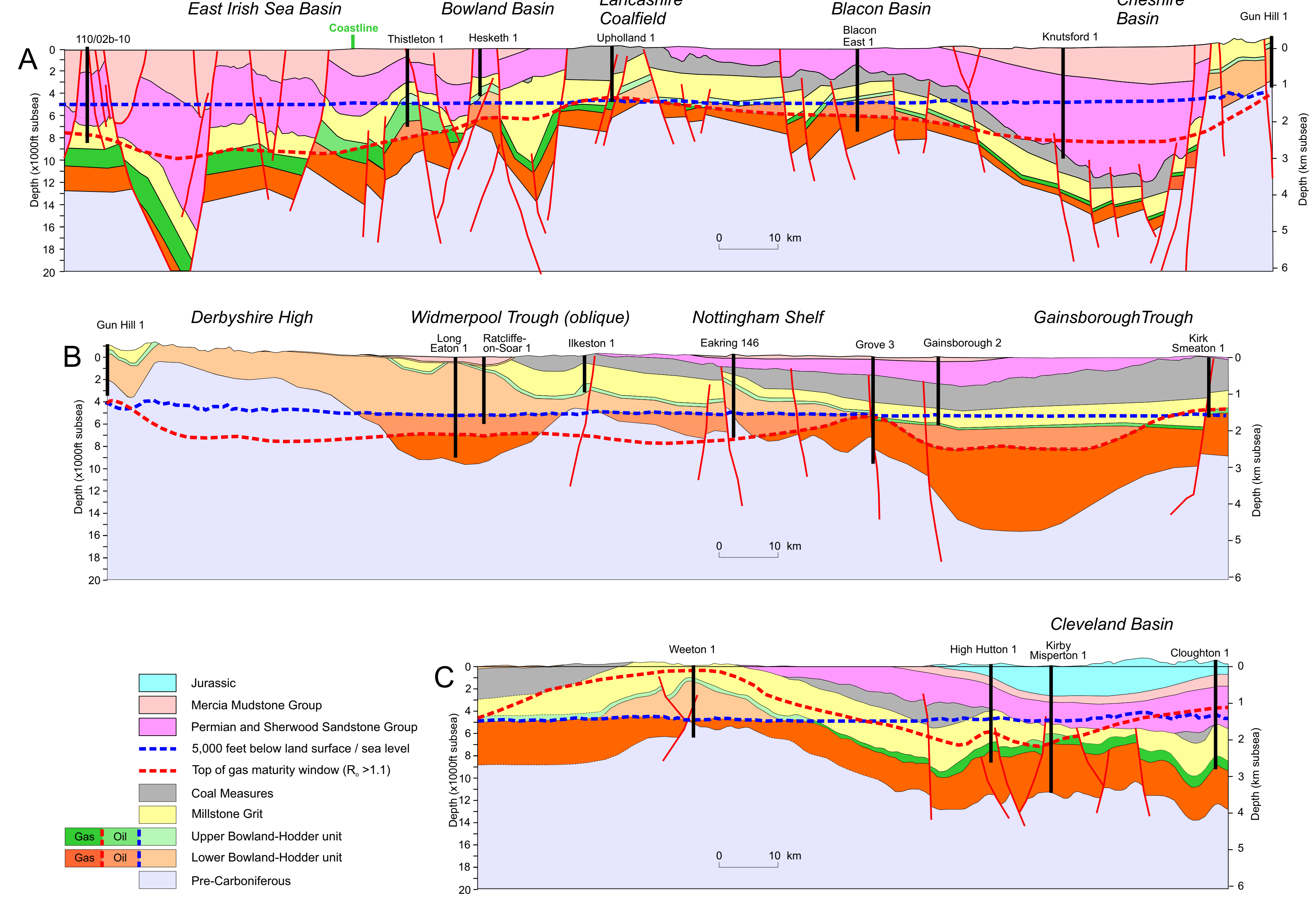


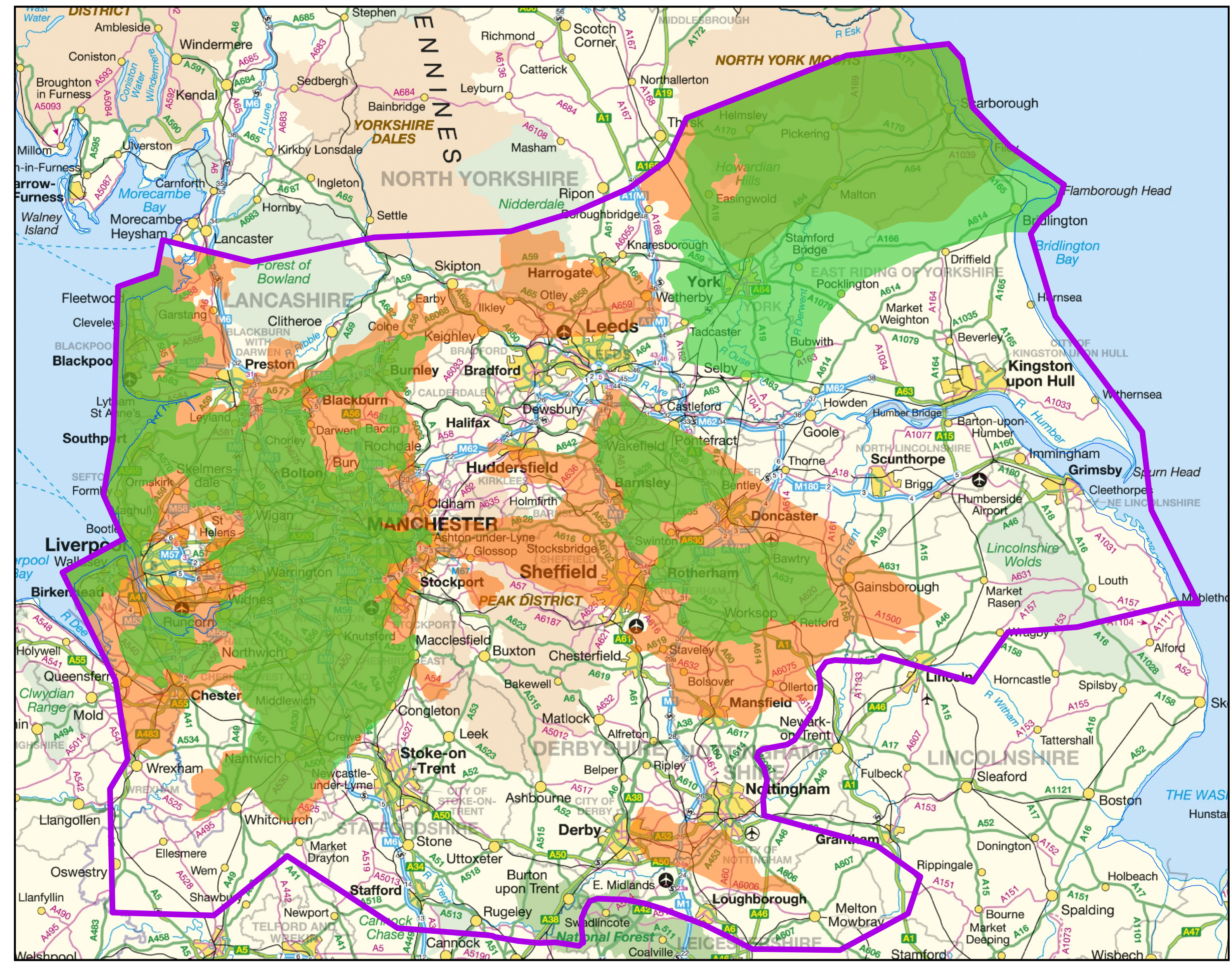

Upper Bowland unit prospective

Lower Bowland unit prospective

\section{BGS/DECC study area}
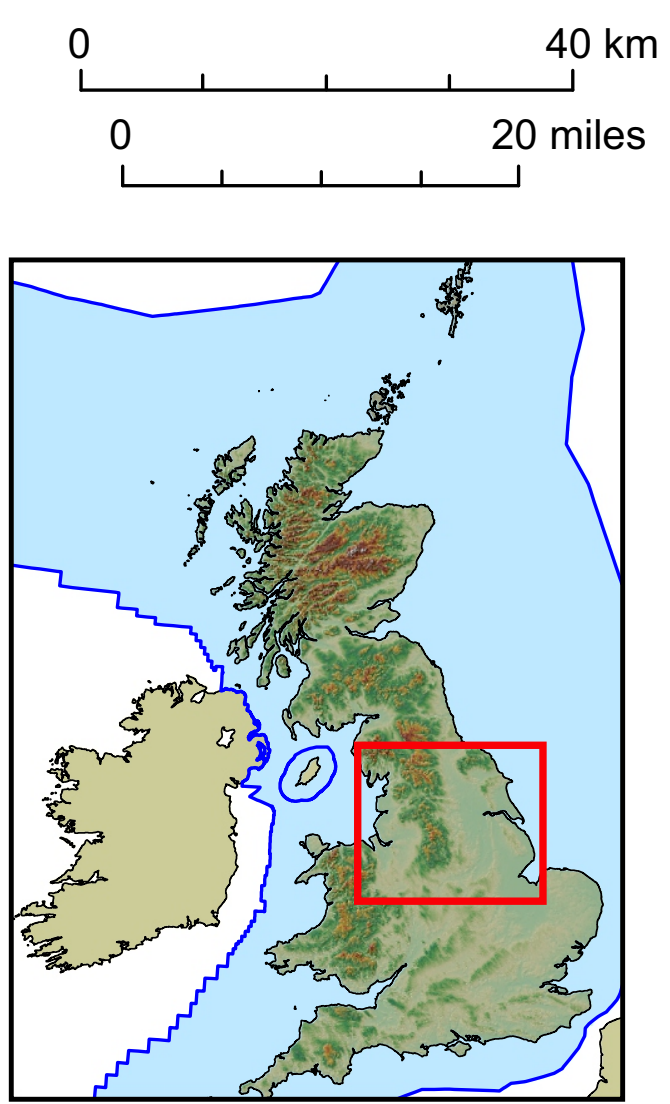
South

North

$\begin{gathered}\text { Portsdown - } \\ \text { Paris Plage Ridge }\end{gathered}$
$\begin{gathered}\text { Littlehampton } \\ \text { Storrington- Bolney } \\ \text { Henfield } \\ \text { Anticline }\end{gathered}$ Anticline
Projected Base Chalk

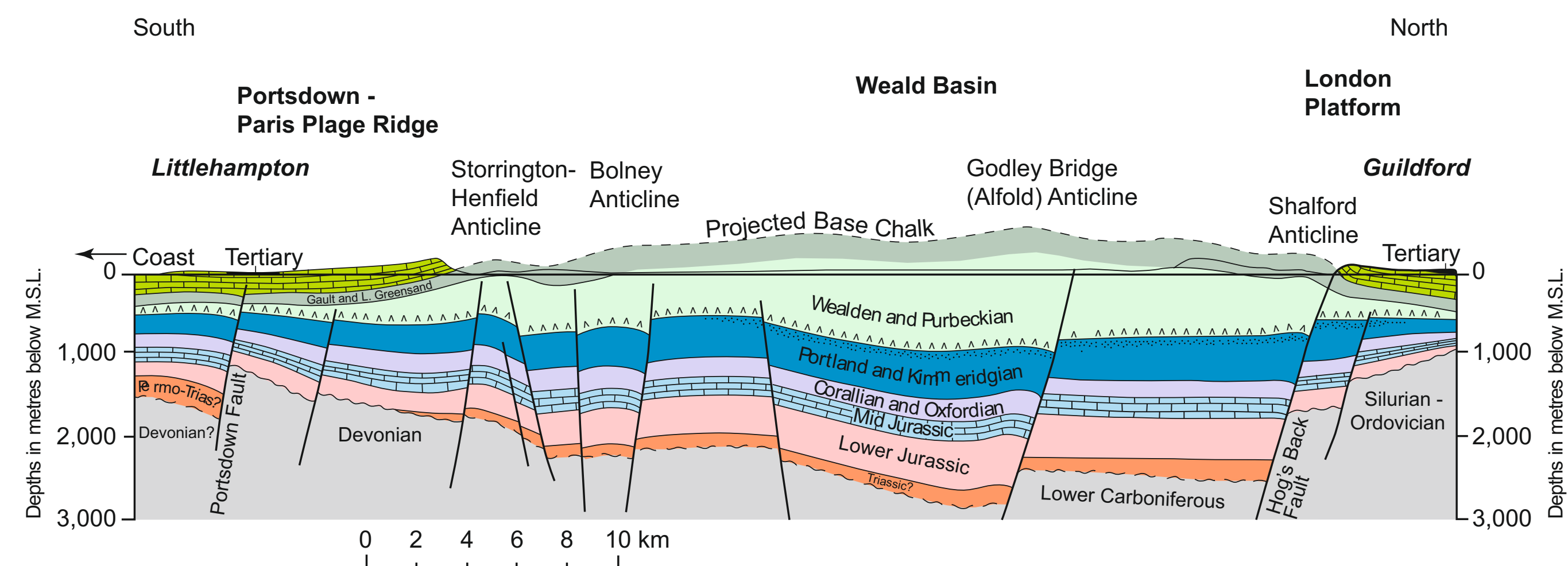




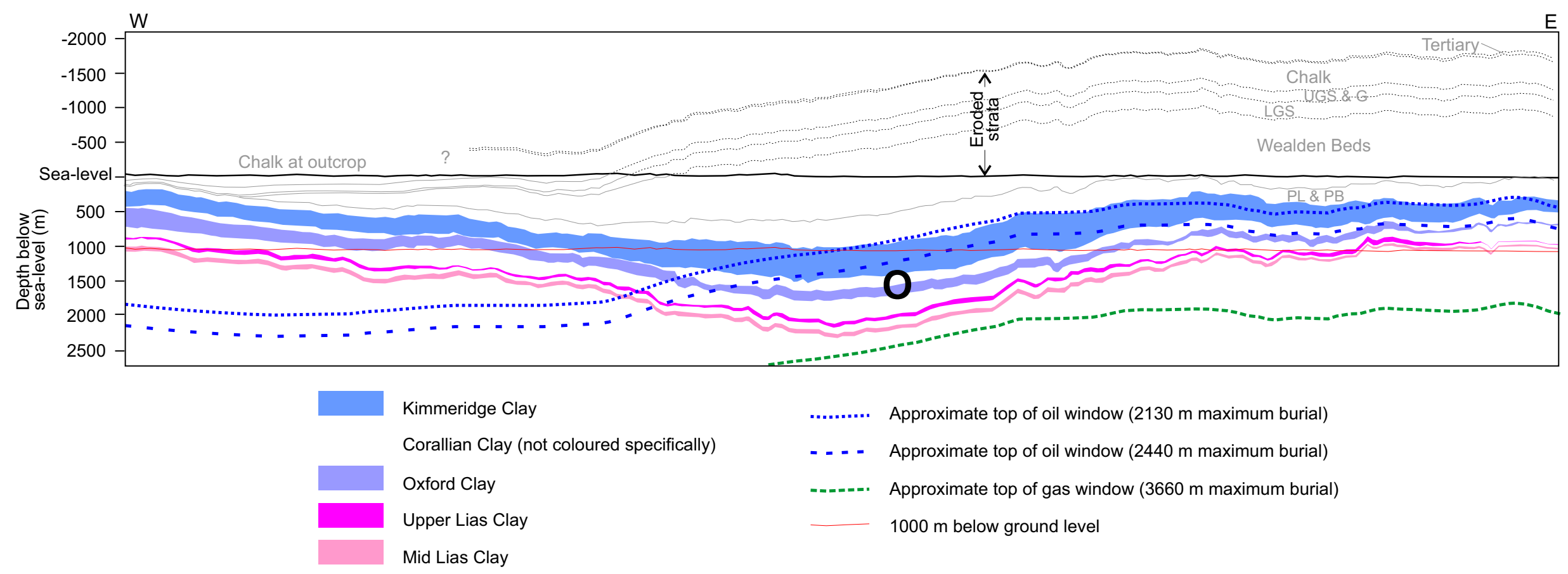




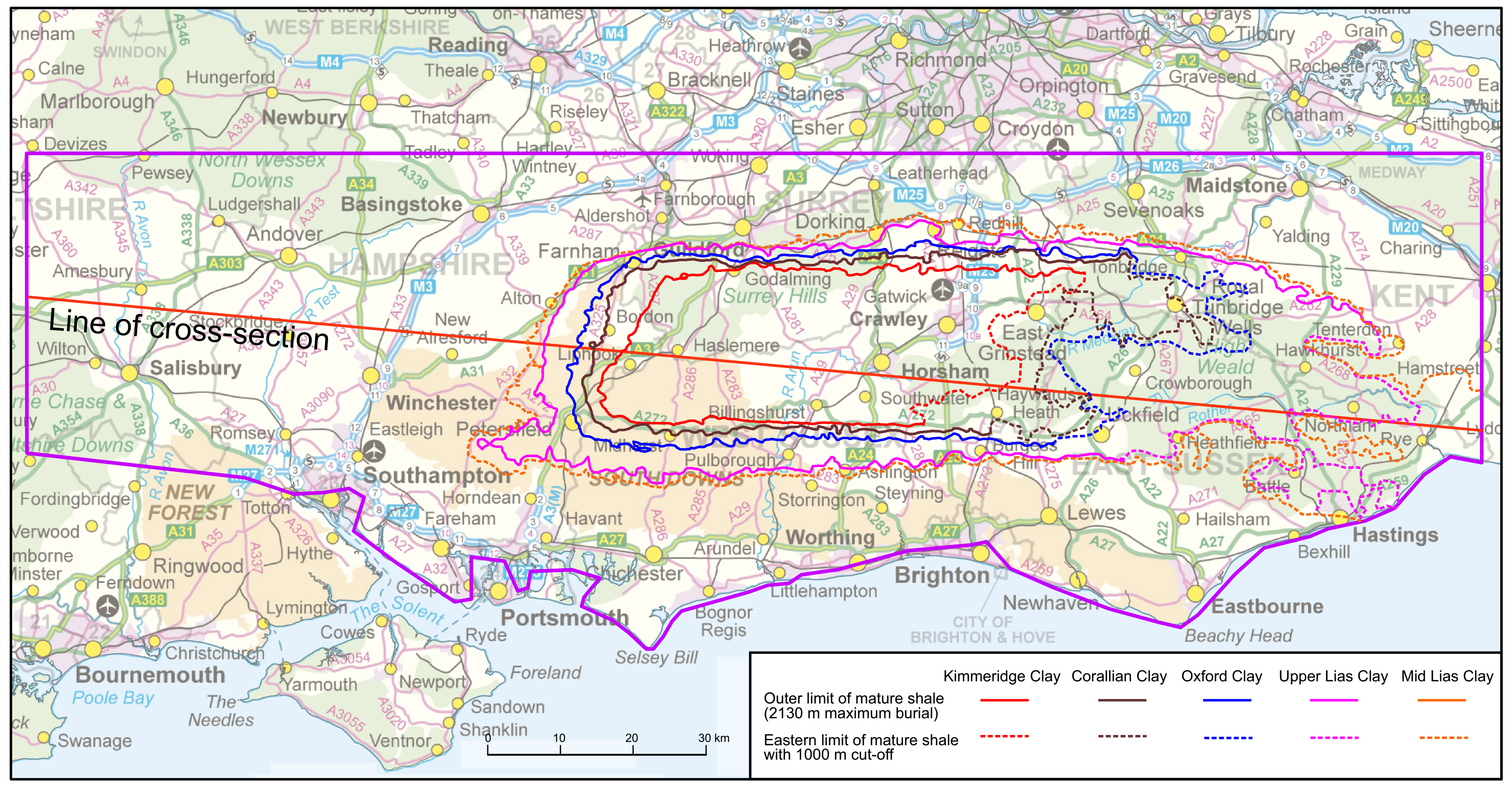


Northern end of the Clackmannan Syncline
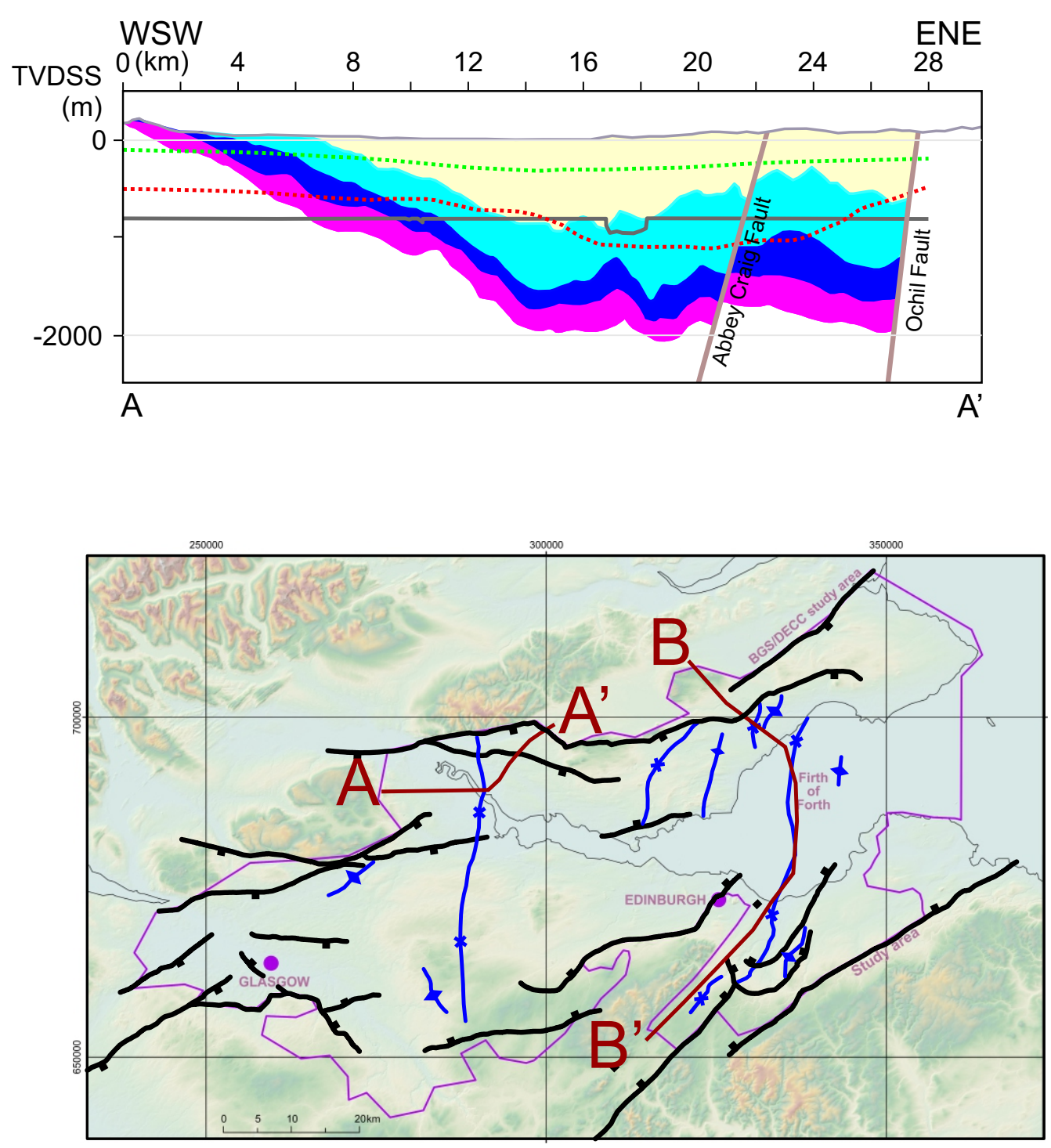

\section{Midlothian-Leven Syncline}

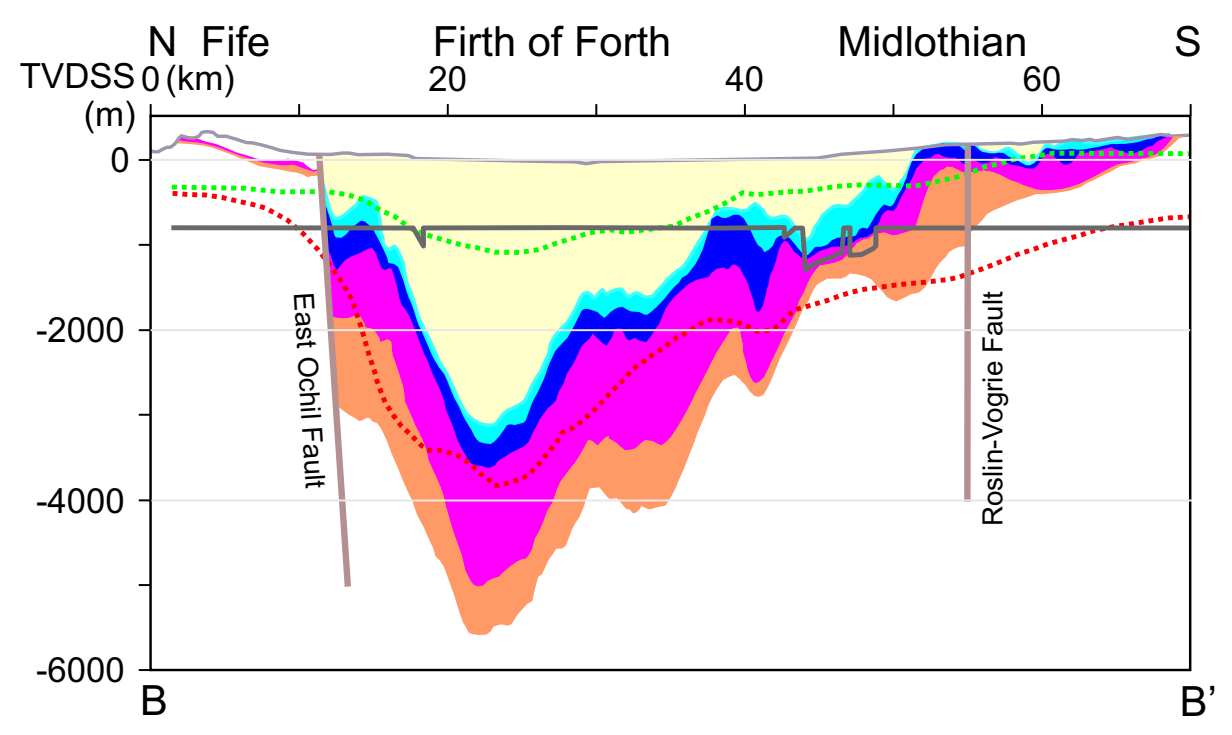

Key

Land surface/sea bed

Upper Limestone Fm and above

- Limestone Coal Fm

- Lower Limestone Fm

- West Lothian Oil-shale unit

- Gullane unit

..... Approximate upper limit of oil maturity

..... Approximate upper limit of gas maturity

- Mining and depth cut-off

- Fault 


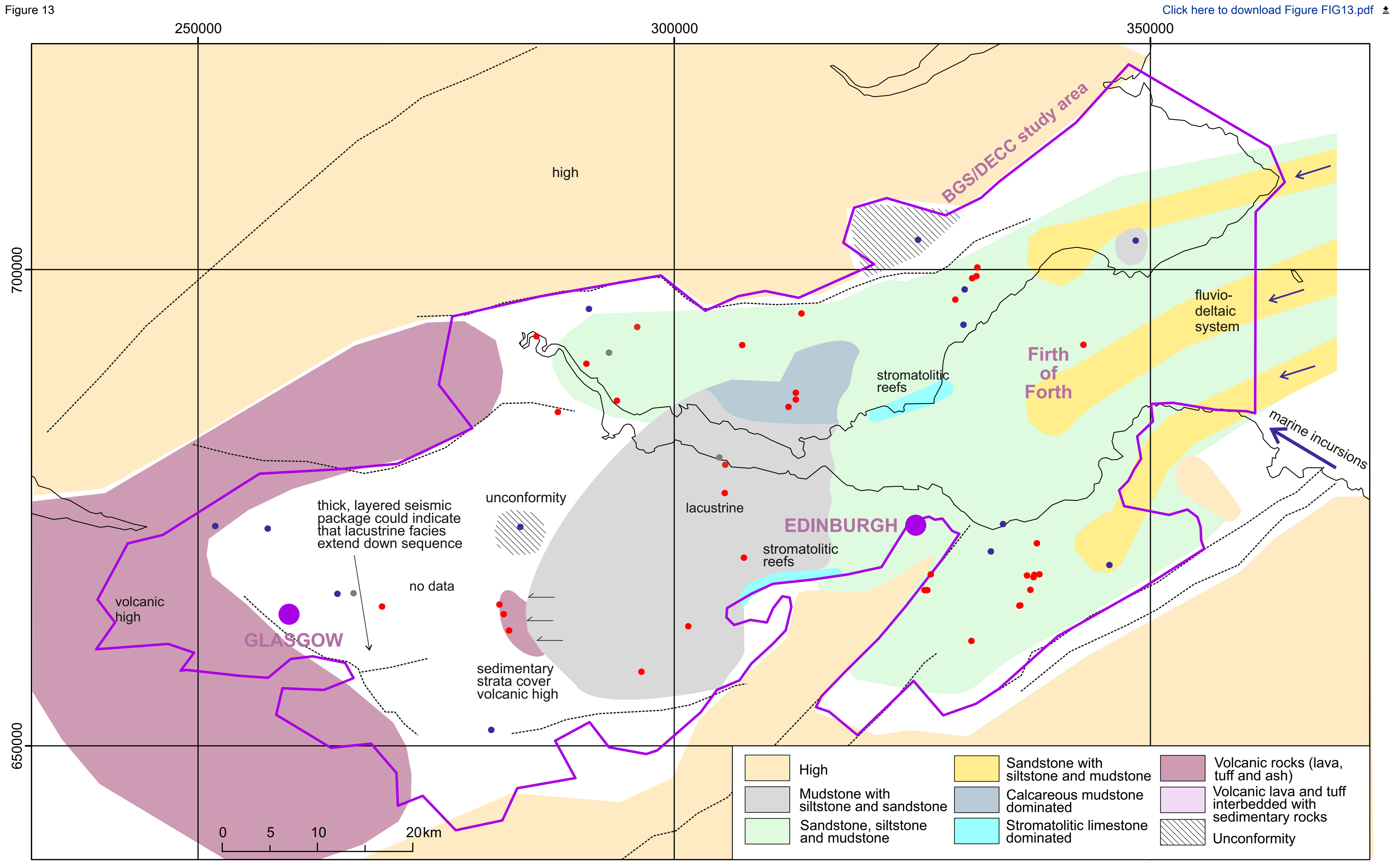




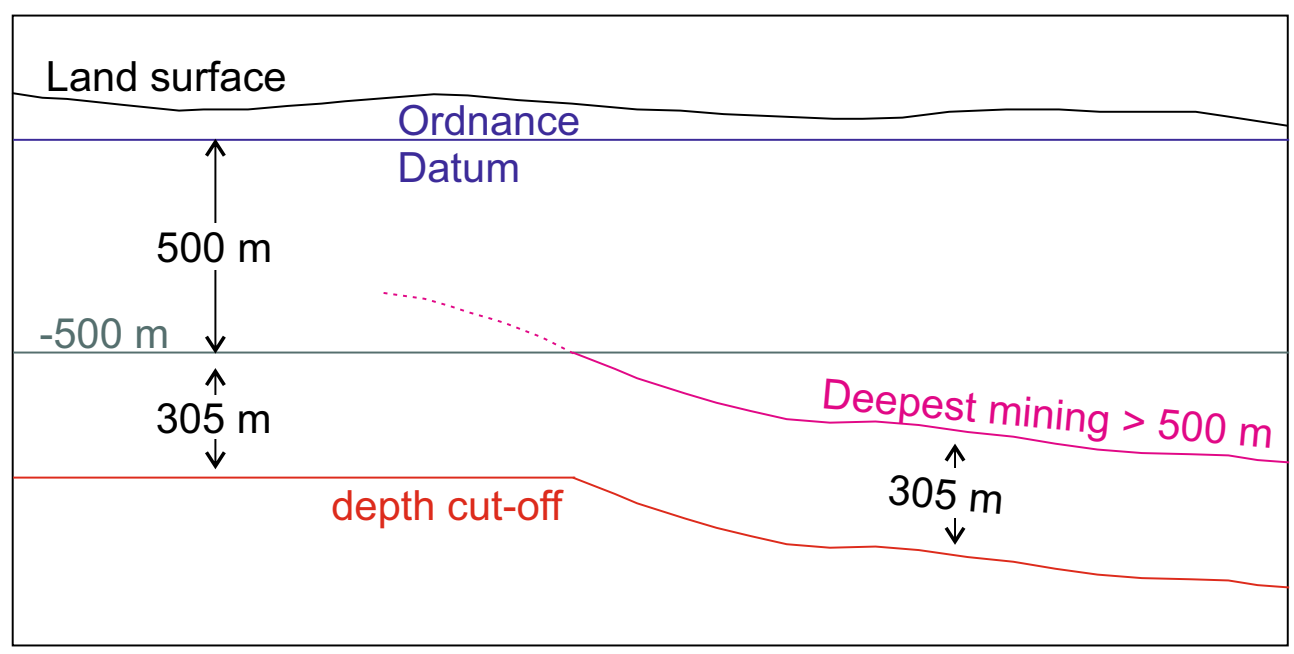




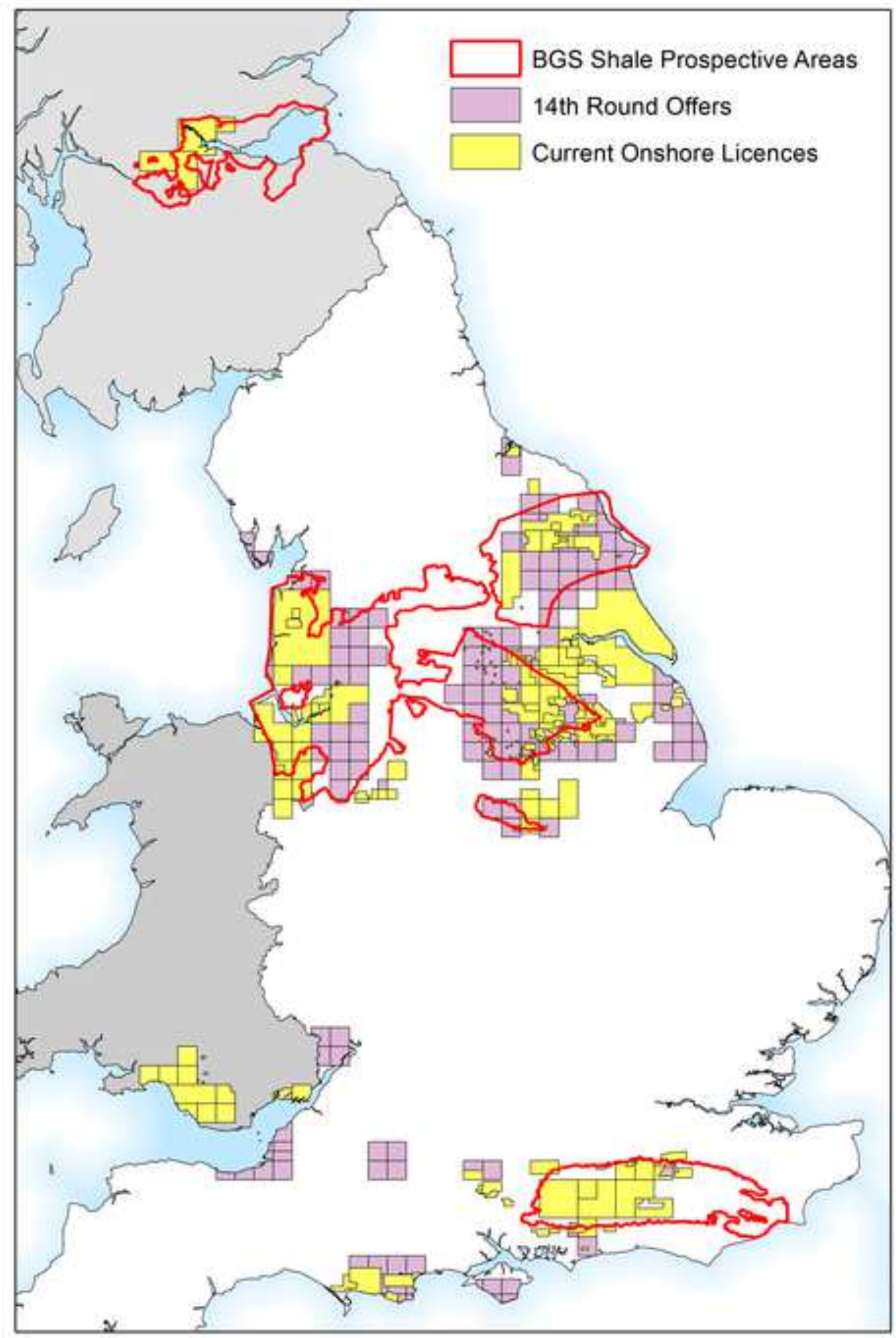

